\title{
Temporal variation in atmospheric ammonia concentrations above seabird colonies
}

\author{
T.D. Blackall , LJ. Wilson , J. Bull , M.R. Theobald , P.J. Bacon , K.C. Hamer , \\ S. Wanless , MA Sutton \\ NERC Centre for Ecology and Hydrology, Edinburgh Research Station, Bush Estate, Midlothian EH26 OQB, UK \\ University of Leeds, Institute of Integrative \& Comparative Biology, Leeds LS2 9JT, UK \\ NERC Centre for Ecology and Hydrology, Banchory Research Station, Hill ofBrathens, Banchory, Aberdeenshire AB31 4BY, UK
}

Keywords:

Ammonia

Emission

Seabird

Nitrogen

Guano

Model

\begin{abstract}
A B S T R A C T
Recent studies have shown that seabirds are an important source of ammonia (NH3) emissions in remote coastal ecosystems. Nesting behaviour, which varies between seabird species, is likely to be a major factor in determining the proportion of excreted nitrogen $(\mathrm{N})$ volatilised to the atmosphere as $\mathrm{NH} 3$. A long-term $\mathrm{NH} 3$ monitoring programme was implemented at a Scottish seabird colony with a range of species and associated nesting behaviours. The average monthly NH3 concentration was measured at 12 locations over a 14-month period, to infer spatial (i.e. species-specific) and temporal (seasonal) changes in $\mathrm{NH} 3$ emissions from different seabird species. An emissions model of seabird NH3, based on species-specific bioenergetics and behaviour, was applied to produce spatial estimates for input to a dispersion model.

Atmospheric NH3 concentrations demonstrated spatial variability as a result of differing local populations of breeding seabirds, with the highest concentrations measured above cliff nesting species such as Common guillemot Una aalge. Razorbill Alca torda and Blacklegged kittiwake Rissa tridactyla. NH3 concentrations above a colony of burrow nesting Atlantic puffin Fratercula arctica were low, considering the high number of birds. Emission of NH3 from excreted N exhibits a time lag of approximately a month. It is likely that all excreted $\mathrm{N}$ is lost from the colony by volatilisation as $\mathrm{NH} 3$ or surface run-off between breeding seasons. Modelled NH3 emissions and concentrations correlated with measured concentrations, but were much higher, reflecting uncertainties in the local turbulent characteristics. The results allow multi-species seabird population data to be used for the calculation of regional and global NH3 emission inventories, whilst improving understanding of $\mathrm{N}$ budgets of remote coastal ecosystems.
\end{abstract}

\section{Introduction}

Ammonia (NH3) is an important atmospheric gas that arises from both natural and anthropogenic sources. The major source of $\mathrm{NH} 3$ is the breakdown of urea or uric acid excretions from animals. Non-biological emissions of NH3 arise from sources such as fertiliser production and vehicle emissions (Sutton et al., 2000). NH3 is an important component of the nitrogen $(\mathrm{N})$ cycle, having the potential to cause both eutrophication and acidification (e.g. Van Breemen et al., 1982; Pearson and Stewart, 1993; Fangmeier et al., 1994; Bouwman et al., 2002). The determination of the magnitude and distribution of NH3 emission sources allows the prediction of their environmental consequences, through the use of atmospheric transport and pollution 
deposition models (e.g. Sutton et al., 1993a-c; Singles et al., 1998; Fournier et al., 2002).

UK NH3 emissions have been estimated at $366 \mathrm{Gg} \mathrm{NH} 3$ $\mathrm{yr}^{-1}$, with $81 \%$ of the emission arising from agriculture and $19 \%$ from non-agricultural sources such as wild animals, sewage treatment, industry and transport (Misselbrook et al., 2000; Sutton et al., 2000). The greater magnitude of agricultural emissions means that research has focused more on the quantification of emissions from this source, with less attention given to emissions from nonagricultural sources. Some studies (e.g. Lee and Dollard, 1994; Sutton et al., 1995, 2000) have addressed the issue of UK NH3 emissions from non-agricultural sources. Of the non-agricultural emission sources identified by Sutton et al. (2000), seabird colonies were highlighted as a source that required further research into both the distribution and magnitude of $\mathrm{NH} 3$ emissions. Wilson et al. (2004) estimated that UK seabirds emit $\sim 2.7 \mathrm{GgNH} 3 \mathrm{yr} \sim 1$ which corresponds to $\sim 1 \%$ of estimated total global seabirds emission of $-242 \mathrm{GgNf}^{\wedge} \mathrm{yr}^{1}$ (Blackall et al., 2007). On a regional scale, seabirds only contribute $\sim 0.7 \%$ of UK NH3 emissions, based on the estimates of Misselbrook et al. (2000) and Wilson et al. (2004). However, by mapping the distribution of UK seabird NH3 emissions, Wilson et al. (2004) highlighted the potential for a significant local effect from seabird $\mathrm{NH} 3$ emissions, as they tend to be most prominent in remote areas with few other sources of NH3 emission (e.g. north and west of Scotland), thus representing major point sources.

There are a variety of reasons why seabird colonies have the potential to be point sources of $\mathrm{NH} 3$ emissions. Seabirds consume a nitrogen-rich diet (e.g. fish and squid) and have high metabolic rates (Birt-Friesen et al., 1989; Bryant and Furness, 1995; Hilton et al., 1998), resulting in high $\mathrm{N}$ excretion rates (primarily as uric acid). Seabird colonies often comprise large numbers of individual birds breeding in a congested space. The crowded nature of seabird colonies creates favourable conditions for the volatilisation of $\mathrm{NH} 3$ from seabird excreta, as the volatilisation of $\mathrm{NH} 3$ increases with the intensity of emission source (Sutton et al., 1995).

There are a number of species-specific traits that are likely to affect the magnitude of $\mathrm{NH} 3$ volatilization from excreted nitrogenous waste, such as bird mass, energy requirement, $\mathrm{N}$ and energy content of food and the assimilation efficiency of the food (Wilson et al., 2004). Other factors that may vary among seabird species include the proportion of time during the breeding season that an individual bird will spend ashore at the colony, nesting behaviour (e.g. bare rock, vegetative nest, burrow). Nesting behaviour is likely to affect the magnitude of volatilised $\mathrm{NH} 3$ being dispersed in the atmosphere. It is known that overlying vegetation and absorption of $\mathrm{NH} 3$ by soil can reduce $\mathrm{NH} 3$ emissions (Nemitz et al., 2000; Misselbrook et al., 2000). As such, vegetation or burrow nesting species such as the Atlantic puffin Fratercula arctica, are likely to result in a lower proportion of $\mathrm{N}$ volatilisation than species which breed on bare ground/rock, such as the Common guillemot Uria aalge.

Here we present data from a 14-month atmospheric NH3 monitoring campaign at a Scottish seabird colony. Data are presented to illustrate temporal patterns in $\mathrm{NH} 3$ emissions from seabirds, differences in the magnitude of $\mathrm{NH} 3$ concentrations near seabirds with varying nesting behaviour and compares measured $\mathrm{NH} 3$ concentration data with outputs from a seabird $\mathrm{NH} 3$ emission model for the Isle of May, Scotland.

\section{Methodology}

\subsection{Study site}

The Isle of May (latitude $56^{\circ} 11^{\prime} \mathrm{N}$, longitude $02^{\circ} 33^{\prime} \mathrm{W}$ ) is located $\sim 8 \mathrm{~km}$ from the Fife coast in the Firth of Forth, Scotland. It is $\sim 1.8 \mathrm{~km}$ long, $\sim 0.5 \mathrm{~km}$ at the widest point and is composed of olivine-dolerite, a hard volcanic rock (Sobey, 1976). The western side of the island is dominated by cliffs of up to $45 \mathrm{~m}$ high, with the elevation of the island decreasing gradually eastwards towards sea level. The vegetation communities of the island are classified as being primarily NVC community MC6 (Atriplex hastata agg.-Beta vulgaris $s p$. Maritima seabird cliff community) at the north and south of the island, with NVC community MC8 (Festuca rubra-Armeria maritima maritime grassland) dominating across most of the inland areas (Bell, 1996). The Isle of May seabird population demonstrates a non-random distribution, with certain species forming colonies. Annual counts of breeding seabird numbers are undertaken by Scottish Natural Heritage. Estimated population numbers for breeding seabird species, based on recent detailed spatial counts by Scottish Natural Heritage (Wilson and Parkinson, 2000 - see Table 1), which are considered to be uncertain to $\pm 5-10 \%$ (M.P. Harris, personal communication).

\subsection{Atmospheric NH3 monitoring}

A monitoring programme for monthly average $\mathrm{NH} 3$ concentration was implemented on the Isle of May in April 2000. The campaign measured the integrated monthly average $\mathrm{NH} 3$ concentration at $0.5 \mathrm{~m}$ above ground level using the CEH ALPHA (Adapted Low-cost Passive High Absorption) sampler system (Tang et al., 2001). Three replicate samplers were exposed at each of 12 locations across the island for periods of approximately one-month duration, from inception to November 2001. The passive sampling stations were located in areas representing a range of different habitats across the island with

Table 1

Population estimates of Isle of May seabirds in 2000 (adapted from Wilson and Parkinson, 2000)

\begin{tabular}{lrl}
\hline Seabird species & Count & Units \\
\hline Puffin, Fratercula arctica & 41,785 & Breeding pairs \\
Guillemot, Uria aalge & 17,384 & Breeding pairs \\
Razorbill, Alca torda & 3,126 & Breeding pairs \\
Kittiwake, Rissa tridactyla & 4,342 & Nests \\
Shag, Phalacrocorax aristotelis & 621 & Nests \\
Fulmar, Pulmonis glacialis & 373 & Nests \\
Herring gull, Larus argentatus & 2,729 & Nests \\
Lesser black-backed gull, Larus fuscus & 1,533 & Nests \\
Great black-backed gull, Larus marinus & 20 & Occupied territories \\
Arctic tern, Sterna paradisaea & 451 & Breeding pairs \\
Common tern, Sterna hirundo & 127 & Breeding pairs \\
\hline
\end{tabular}


contrasting local populations of breeding seabirds. The locations of the passive sampling stations are shown in Fig. 1, whilst descriptions of each of the 12 sites are given in Table 2. An automated weather station was also operated on the Isle of May for the duration of the monitoring campaign (see Fig. 1 for location). Hourly-averaged measurements of wind speed and direction, temperature and relative humidity were made at $1.5 \mathrm{~m}$ above ground level.

\subsection{Ammonia emissions modelling for Isle of May seabirds}

In order to estimate total $\mathrm{NH} 3$ emissions from Isle of May seabirds on a spatial basis, a model was constructed to predict emissions based on seabird bioenergetics and behaviour. The model estimates $\mathrm{N}$ excretion at the colony, by species, as $\mathrm{N}_{\mathrm{eX}} \mathrm{cr}\left(\mathrm{g} \mathrm{N}_{\text {bird }}^{-1} \mathrm{day}^{-1}\right)$ :

$$
\mathrm{J}^{*} \text { excr }-\frac{\mathrm{FMRxF}_{\mathrm{Nc}}}{r \text { Ec X/iefflc }}
$$

where FMR is the field metabolic rate (differentiated for adults and chicks; kjbird ${ }^{-1} \mathrm{day}^{-1}$ ), $\mathrm{FN}_{\mathrm{C}}$ is the $\mathrm{N}$ content of the food (typically $0.036 \mathrm{~g} \mathrm{Ng}^{-1}$ wet mass), $\mathrm{F}_{\mathrm{Ec}}$ is the energy content of the food (typically $6.5 \mathrm{kj} \mathrm{g}^{-1}$ wet mass) and Aefflc is the assimilation efficiency (assumed $0.8 \mathrm{kj}$ [energy obtained] $\mathrm{kj}^{-1}$ [energy in food]). Adult FMR values were estimated to be basal metabolic rate (BMR) multiplied by 4 (Bryant and Furness, 1995), with BMR values being available from the literature. The estimated total energy metabolised by chicks between hatching and fledging was used in place of FMR. These values were based on the calculations of Weathers (1992). Total seabird N excretion at the Isle of May was estimated as a function of $\mathrm{N}_{\text {excr }}$, the seabird population size and attendance of seabird species at the colony during the breeding season. It is assumed that the proportion of a bird's total $\mathrm{N}$ excretion at the colony is

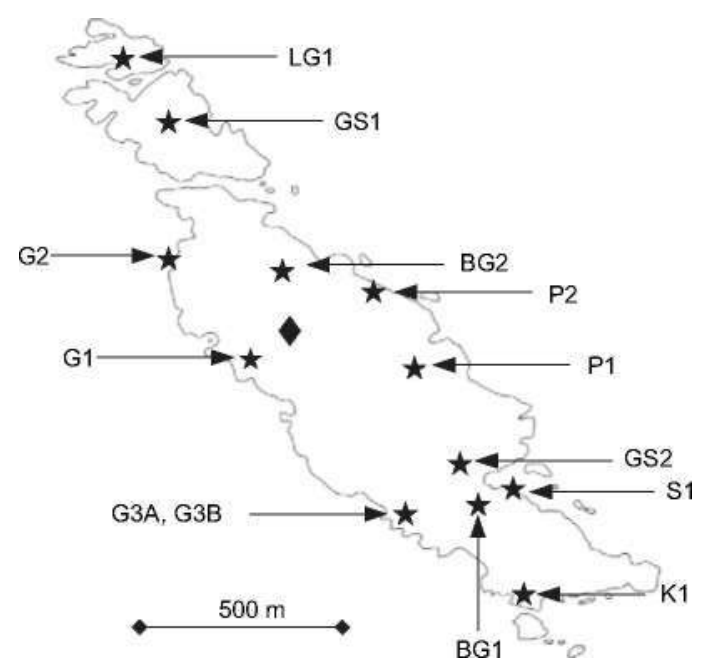

Fig. 1. A map of passive $\mathrm{NH}_{3}$ monitoring locations (stars) and meteorological station (diamond) on the Isle of May. the same as colony attendance (see Wilson et al., 2004 for colony attendance periods for different UK seabird species). All factors were species-specific and varied between cohort (breeding adult, non-breeding adult, chick), where appropriate. NH3 emissions were estimated by applying an emission factor of 0.3 to all $\mathrm{N}$ excretion values, based on the measurements of Blackall et al. (2004). These NH3 emission potentials were then standardised according to nesting behaviour of different species, with the assumption that bare rock breeders (guillemot, Razorbill Alca torda) would volatilise $100 \%$ of potential $\mathrm{NH} 3$ emissions, vegetation nesters (Black-legged kittiwake Rissa tridactyla, European shag Phalacrocorax aristotelis, large gulls Larus sp., Northern fulmar Fulmarus glacialis) would volatilise $70 \%$ of potential $\mathrm{NH} 3$ emissions and burrow nesters (puffin) would volatilise $20 \%$ of potential $\mathrm{NH} 3$ emissions. It is clear that the actual relative amounts of emissions between these nesting categories need to be compared with measurements (e.g. Blackall et al., 2007), and the present study contributes to this. A more detailed explanation of the seabird bioenergetics and $\mathrm{NH} 3$ emission model is provided by Wilson et al. (2004). The volatilisation potentials applied in this study vary slightly from those used by Wilson et al. (2004), but a sensitivity analysis has shown these differences to only alter whole colony $\mathrm{NH} 3$ emissions from the Isle of May by $6 \%$, and therefore cannot account for the larger discrepancies noted between the model and measured ammonia air concentrations.

A Geographical Information System (GIS) was used to model $\mathrm{N}$ excretion and $\mathrm{NH} 3$ emissions on a spatial basis for the Isle of May. The model was calculated using a 25 x $25 \mathrm{~m}$ grid, which allowed for detailed interpretation of spatial patterns of $\mathrm{NH} 3$ emission.

\subsection{Ammonia dispersion modelling for Isle of May}

NH3 dispersion modelling across the Isle of May was performed using the LADD (Local Area Dispersion and Deposition) model, which is a multi-layer statistical trajectory model described in detail by Hill (1997) and Dragosits et al. (2002). The model input files, which describe general parameters, include NH3 emissions, landuse, wind and boundary conditions. General parameters were grid cell dimensions ( $25 \mathrm{~m} \times 25 \mathrm{~m})$, number of grid cells per domain edge (120), angle increment for wind data (10 degrees) and atmospheric stability (3, slightly unstable). Emissions data were generated using the bioenergetics model described above, for each $25 \mathrm{~m}$ x $25 \mathrm{~m}$ grid cell, on a monthly basis (as $\mid$ ig $\mathrm{NH} 3 \mathrm{~m}^{-2} \mathrm{~s}^{-1}$ ). An $x$ and $y$ co-ordinate for each emission value corresponded to the centre point of each grid cell. Land use data from the $\mathrm{CEH}$ Land Cover Map of Great Britain (LCM, 1990) classified each grid cell into one of six categories: rocks/beach; water; semi-natural rough; semi-natural smooth; lowland bog; and buildings. These land-use types determine the values of roughness length (zo) and canopy resistance $\left(r_{c}\right)$ applied for each grid cell by the LADD model. Wind data describe the boundary layer height (nominally set to $500 \mathrm{~m}$ ), average wind speed for each 10 degree sector and the probability of the wind blowing in each sector during the modelled period. The boundary conditions describe the 
Table 2

Passive $\mathrm{NH}_{3}$ sampling station site descriptions for the Isle of May

Site Most abundant seabird species Brief site description

PI Puffin

P2 Puffin

Gl Guillemot

High puffin burrow density (4342 occupied burrows). Ground slopes from west to east. Vegetation dominated by Yorkshire fog Holcus lanatus.

High density of puffin burrows (2490 occupied burrows). Ground slopes from west to east. Vegetation dominated by $H$. lanatus.

Some of the highest and most densely occupied guillemot cliffs on the Isle of May. First guillemot ledges were approximately $1 \mathrm{~m}$ below $\mathrm{NH}_{3}$ samplers. Razorbills (fewer than 60), kittiwakes (fewer than 100) and shags (fewer than 40) on the cliffs below the samplers

G2 Guillemot Above guillemot cliffs approximately $200 \mathrm{~m}$ northwest of the lighthouse. Approximately $30 \mathrm{~m}$ between the cliff edge and the first guillemot ledge below. A number of puffin burrows located a few metres inland from passive sampling station. Minimal vegetation cover.

G3a Guillemot Passive sampling system attached to the side of a shelter overhanging cliff, air channelled upwards in periods of westerly winds. Densely occupied guillemot ledge (around 300 pairs) approximately $10 \mathrm{~m}$ below the samplers. Not used for monthly sampling after 14 June 2000, but used for 'over cliff monitoring in 2001.

G3b Guillemot Samplers located on the side of a bird viewing hide, approximately $3 \mathrm{~m}$ along cliff edge from site G3a. Monitored from 14 June 2000.

SI Shag

Kl Kittiwake

GS1 Grey seal (winter); Large gulls/puffin (summer)

GS2 Grey seal (winter); background site (summer)

BG1 Background site

BG2 Background site
Passive sampling station sited in a rocky area adjacent to the channel leading up to Kirkhaven harbour, on the east of the island. Surrounded by approximately 50 pairs of nesting shags and some large gulls.

Passive sampling station located approximately $30 \mathrm{~m}$ northeast of a $30 \mathrm{~m}$ high cliff face, with approximately 50 kittiwake sites and approximately 10 fulmar nests. A number of shags were nesting towards the bottom of the cliffs. Location was chosen to represent an area of grey seal Halichoerus grypus breeding during winter months.

The samplers were situated approximately $15 \mathrm{~m}$ northeast of the northern foghorn. During the summer months this area has a mixture of large gulls and puffins. Vegetation is primarily H. lanatus, but becomes bare mud in the winter months owing to disturbance of vegetation by grey seals moving back and forth to the sea. Location was chosen to represent an area of grey seal breeding during winter months. Passive samplers were sited approximately $20 \mathrm{~m}$ west of the Kirkhaven harbour jetty on the east of the island, approximately $0.5 \mathrm{~m}$ away from a $2 \mathrm{~m}$ high wall. In the summer there were only a few eiders observed in close proximity to the passive samplers. Thick growth of stinging nettle Urtica dioica in summer.

Approximately $30 \mathrm{~m}$ southwest of the Kirkhaven harbour, in area surrounded by $1 \mathrm{~m}$ high stone walls. Very low bird occupancy (background $\mathrm{NH}_{3}$ site for Isle of May), occasional grey seal pup nearby in winter. Vegetation dominated by short grass, with abundant rabbit population.

Located in the centre of the island. Exposed position, vegetation dominated by short grass, abundant local rabbit population. Very low bird occupancy (background $\mathrm{NH}_{3}$ site for Isle of May), with large gulls or oystercatcher Haematopus ostralegus observed infrequently.
NH3 concentration along the boundaries of the domain, which was set to zero. For each grid cell, the model was used to generate $\mathrm{NH} 3$ concentration (|igNH3irT ${ }^{3}$ ) at two heights $(0.5,1.5 \mathrm{~m})$.

\section{Results}

The background NH3 concentration, determined at sites BG1 and BG2, varied from 0.4 to 7.5 ig rrT $^{3}$ with a mean concentration from all monthly determinations at BG1 and BG2 of 2.6|igrrT ${ }^{3}$ (standard deviation $=2.2 \mid$ ig $\operatorname{rrT}^{3}$ ). The $\mathrm{NH} 3$ concentration above guillemot cliffs, determined at sites G1 and G2, varied from 1.1 to 47.5 ig rrT $^{3}$ with a mean concentration from all monthly determinations at $\mathrm{Gl}$ and $\mathrm{G} 2$ of $16.1 \mid \operatorname{igrrr}^{3}$ (standard deviation $=14.6 \mid \operatorname{igrrr}^{3}$ ). The $\mathrm{NH} 3$ concentration at the puffin colony, determined at sites PI and P2, varied from 0.8 to 27.8 ig rrT $^{3}$ with a mean concentration from all monthly determinations at PI and P2 of $8.7 \mid$ igrrr $^{3}$ (standard deviation $=9.1 \mid$ igrrr $^{3}$ ). There were a few occasions when ALPHA samplers were lost from or contaminated at the sampling station, owing to wind damage or interference by animals. Destructive high winds in mid-June 2000 necessitated the relocation of the passive sampling system at site G3. Over all sites for the duration of sampling, triplicate measurements (or duplicate where one sampler was lost or contaminated) generated an average coefficient of variation of $10.4 \%$.

The temporal patterns of NH3 concentration near guillemots, puffins and in areas of low bird activity on the Isle of May are shown in Fig. 2, which illustrates the increased atmospheric NH3 concentration across the whole of the island associated with the seabird breeding season. The concentration peaks were highest above the guillemot cliffs, with maximum average $\mathrm{NH} 3$ concentrations of 49 |ig $\mathrm{rrr}^{3}$ in June 2000 and 83 ig rrT $^{3}$ in June 2001. Seasonal maximum concentrations in the puffin colony reached $22 \mathrm{Vig} \mathrm{m} \sim^{3}$ in July 2000 and $31 \mathrm{Vig} \mathrm{m} \sim^{3}$ in July 2001. Seasonal maximum concentrations at the sites with low bird activity reached 6 lig $\mathrm{rrr}^{3}$ in August 2000 and 8 lig $\mathrm{rrr}^{3}$ in July 2001.

Non-parametric comparison of monthly NH3 concentrations (Wilcoxon signed ranks test) at sites PI and P2 was not significantly different $(Z=-0.247, p=0.81)$, with $B G 1$ and BG2 also showing no significant difference $\{Z=-1.667$, $\mathrm{p}=0.10)$. Sites $\mathrm{Gl}$ and $\mathrm{G} 2$ did show a significant difference over the whole sampling period $(Z=-2.794, p=0.01)$, but there was no significant difference between G1 and G2 during the 2000 seabird breeding season (AprilSeptember; $Z=-1.572, p=0.12$ ). Inspection of the $\mathrm{NH} 3$ concentration data for site G2 reveals unusually low concentrations after April 2001, in July 2001 falling below the concentration at background sites. To ascertain differences in $\mathrm{NH} 3$ concentration between colonies of different bird species, the monthly concentrations for puffins (PI and P2) and background sites (BG1 and BG2) were averaged. For guillemots, the data used for comparison with puffin and background averages was an average of Gl and G2 between April 2000 and April 2001, and G1 data 

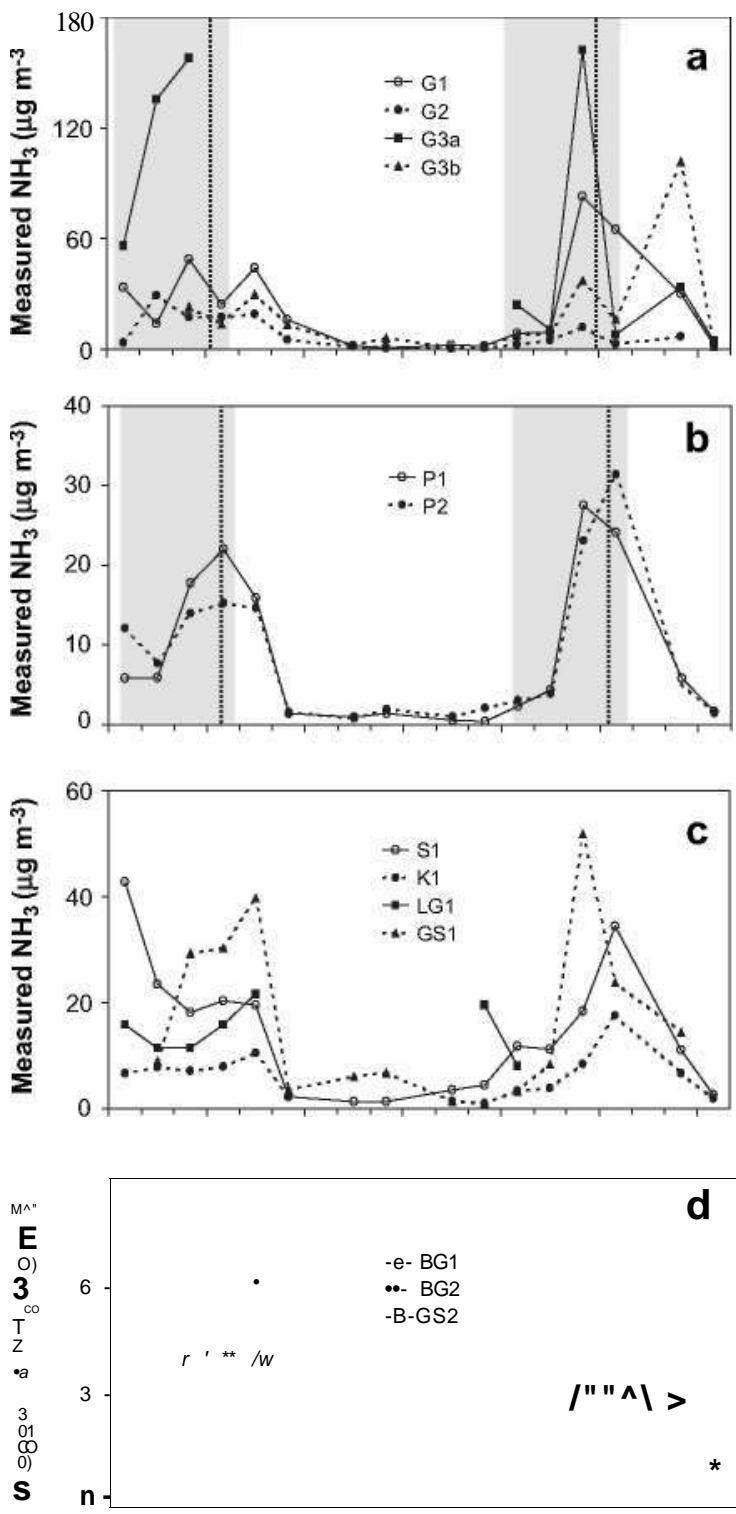

0

o

Fig. 2. Temporal patterns in atmospheric $\mathrm{NH}_{3}$ concentration at Isle of May passive sampling stations occupied (primarily) by (a) guillemot/razorbill, (b) puffin, (c) various species (shag; kittiwake; large gulls; grey seal) and (d) low numbers of birds (background). Shaded areas on (a) and (b) represent the periods of bird occupancy by guillemot/razorbill and puffin, respectively. Vertical dotted lines on (a) and (b) represent average fledging date for guillemot/razorbill and puffin, respectively. More detailed information about monitoring sites is given in Table 2 .

only for April 2001 onwards. Non-parametric comparison of the mean monthly $\mathrm{NH} 3$ concentrations (Wilcoxon signed ranks test) at guillemot, puffin and background sites showed that there were significant differences for all three comparisons ( $\mathrm{G}$ vs. BG: $Z=-3.516, p=0.000$; $\mathrm{P}$ vs. $\mathrm{BG}$ : $Z=-3.516, p=0.000$; G vs. $P: Z=-3.413, p=0.001)$.

The seasonal increase in $\mathrm{NH} 3$ concentration at background sites occurs in tandem with those observed for guillemot and puffin sites (Figs. 2 and 3). There is a significant correlation between concentrations at guillemot and background sites (Pearson correlation $=0.873$, significant at 0.01 level, $\mathrm{n}=16$ ) and puffin and background sites (Pearson correlation $=0.948$, significant at 0.01 level, $\mathrm{n}=16$ ). Fig. 2 shows that $\mathrm{NH} 3$ concentrations remain elevated at the Isle of May beyond the period of the main breeding season for seabirds.

The Isle of May NH3 emission model predicted peaks in June for all locations on the Isle of May where passive NH3 monitoring sites were located. Comparison of the $\mathrm{NH} 3$ emission estimates with observed $\mathrm{NH} 3$ concentrations at guillemot, puffin and background sites during April 2000 to September 2001, are shown in Fig. 4. There is an apparent 'time lag' between the predicted peak in $\mathrm{NH} 3$ emission and the observed peak in NH3 concentration, with no significant correlation between measured $\mathrm{NH} 3$ concentration and modelled $\mathrm{NH} 3$ emission for any site, when data for each month are compared (Table 3). To account for the apparent lag, correlation between emission and concentration was re-analysed, using an adjustment factor of 'month +1 ' for concentration (e.g. correlate modelled emission for $\mathrm{Gl}$ in June 2000 with measured concentration for Gl in July 2000). These correlations are detailed in Table 3 . The time lag correlation increased the strength of the positive correlation between emission and concentration for all sites, with significant correlations for PI, P2 and BG1 (0.05 level, 2-tailed).

Fig. 5 shows that the spatial representation of $\mathrm{NH} 3$ concentrations across the Isle of May after modelling with LADD are as expected, i.e. the highest concentrations are over the guillemot cliffs on the west coast of the island, whilst low concentrations are predicted in central areas of the island with low bird occupancy. These patterns correlate with the observations from the passive monitoring campaign. However, $\mathrm{NH} 3$ concentrations are overestimated by the LADD model (e.g. up to $900 \mid$ ig irT $^{3}$ modelled by LADD, compared with a maximum measured concentration of 163 ig $\operatorname{irT}^{3}$ ). Measured NH3 concentrations were thus much lower than those predicted by the LADD model. There was a positive correlation between measured and modelled concentrations for cliff sites, but not inland locations (Fig. 6). Future research efforts should focus on

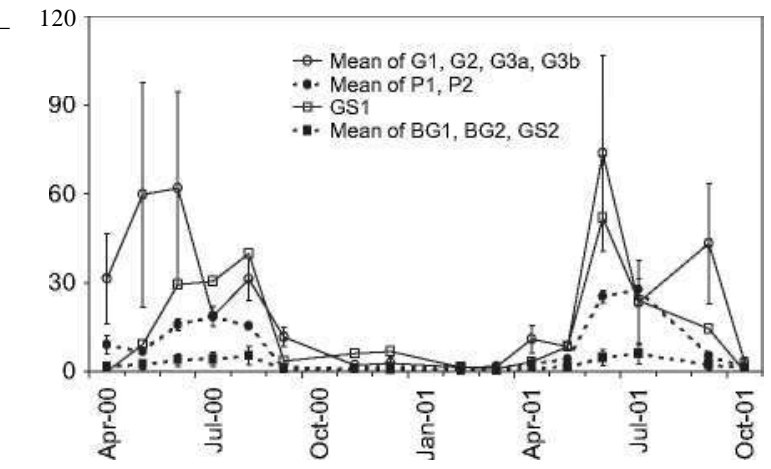

Fig. 3. Comparison of average measured $\mathrm{NH}_{3}$ concentrations between areas occupied by different bird species ( $(\mathrm{Gl}, \mathrm{G} 2, \mathrm{G} 3 \mathrm{a}, \mathrm{G} 3 \mathrm{~b}=$ guillemot/razorbill; PI, P2 = puffin; BG1, BG2, GS2 = background/low bird occupancy) and grey seals (GS1)). 


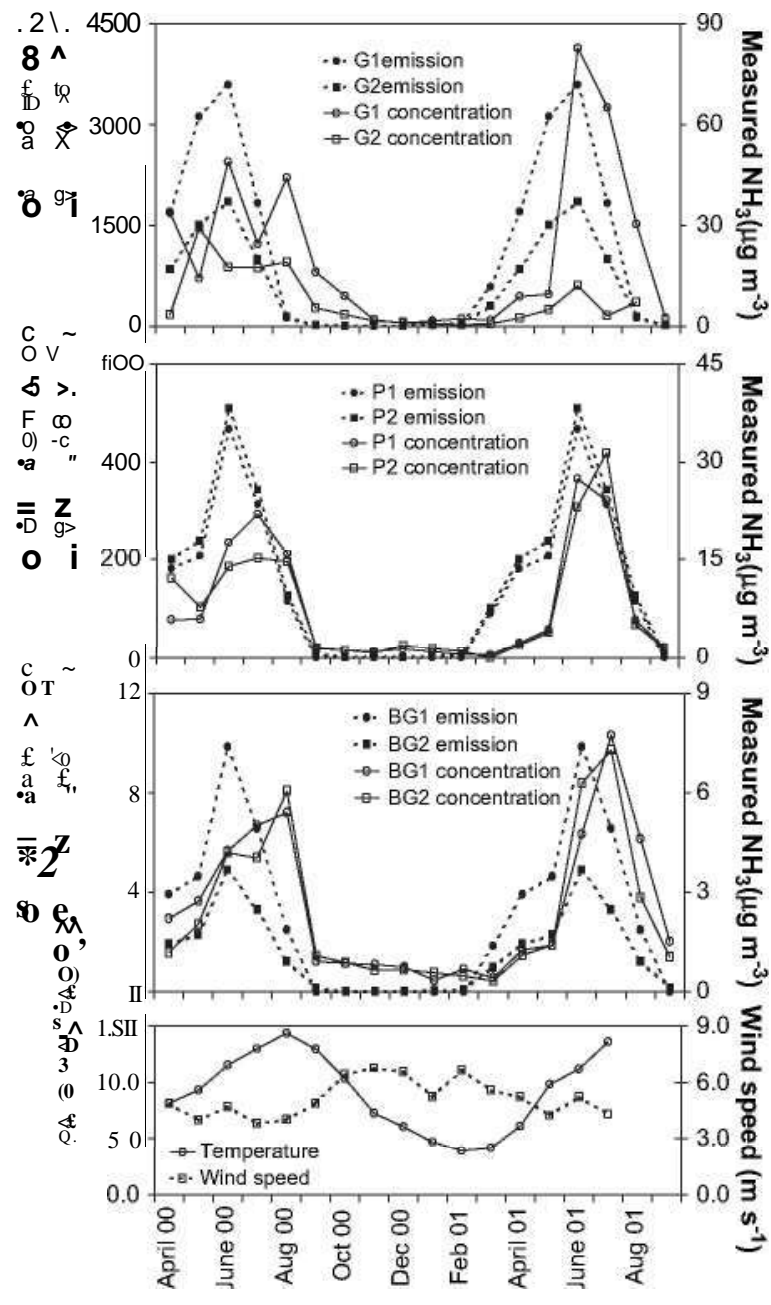

Fig. 4. Comparison of modelled $\mathrm{NH}_{3}$ emissions with measured $\mathrm{NH}_{3}$ concentrations for guillemot, puffin and background locations on the Isle of May. Air temperature and wind speed at $1.5 \mathrm{~m}$ above ground are also presented for the corresponding period.

more robust determination of the effect nesting behaviour has on seabird $\mathrm{NH} 3$ volatilisation potential, as this remains particularly uncertain for vegetation or burrow nesting species.

\section{Discussion}

As expected, the period of maximum $\mathrm{NH} 3$ concentration was during the summer months, when numbers of breeding seabirds are highest. Comparison of modelled emissions and measured concentrations of $\mathrm{NH} 3$ for the same location on the Isle of May (Fig. 4) provides evidence of a time lag between excretion and $\mathrm{NH} 3$ volatilisation during the breeding season of seabirds. There was also evidence of elevated $\mathrm{NH} 3$ concentrations after the departure of breeding seabirds from the colony in late summer (Fig. 2). This time lag from $\mathrm{N}$ excretion (as uric acid) to $\mathrm{NH} 3$ volatilisation is likely to be controlled by two factors: (i) the microbial decomposition of uric acid to ammonium and
Table 3

Correlations between monthly measured $\mathrm{NH}_{3}$ concentrations and modelled $\mathrm{NH}_{3}$ emissions where (i) measured concentration and modelled $\mathrm{NH}_{3}$ emission are for the same time period and (ii) modelled emission is correlated with the measured concentration for the subsequent 30 day period (i.e. month +1 )

\begin{tabular}{lllll}
\hline Site & \multicolumn{2}{l}{$\begin{array}{l}\text { (i) Measured month vs. } \\
\text { modelled month }\end{array}$} & \multicolumn{2}{l}{$\begin{array}{l}\text { (ii) Measured month }+1 \text { vs. } \\
\text { modelled month }\end{array}$} \\
\cline { 2 - 5 } & $\begin{array}{l}\text { Pearson } \\
\text { correlation }\end{array}$ & $\begin{array}{l}\text { Significance } \\
\text { (2-tailed) }\end{array}$ & $\begin{array}{l}\text { Pearson } \\
\text { correlation }\end{array}$ & $\begin{array}{l}\text { Significance } \\
\text { (2-tailed) }\end{array}$ \\
\hline G1 & 0.129 & 0.808 & 0.657 & 0.156 \\
G2 & 0.495 & 0.319 & 0.619 & 0.190 \\
PI & 0.693 & 0.127 & 0.889 & $0.018^{\mathrm{a}}$ \\
P2 & 0.642 & 0.170 & 0.876 & $0.022^{\mathrm{a}}$ \\
BG1 & 0.527 & 0.282 & 0.876 & $0.022^{\mathrm{a}}$ \\
BG2 & 0.347 & 0.500 & 0.766 & 0.076 \\
\hline
\end{tabular}

a Significant correlation at 0.05 level.

(ii) flux rate of $\mathrm{NH} 3$ from surface pools to the atmosphere. The rate of ammonification is influenced by temperature, pH and water availability (Elliot and Collins, 1982; Elzing and Monteny, 1997; Koerkamp et al., 1998), as will flux rates of $\mathrm{NH}_{3}$ (Sutton et al., 1994; Nemitz et al., 2001). A more detailed investigation into the physical and chemical parameters controlling $\mathrm{NH} 3$ emissions from seabirdexcreted $\mathrm{N}$ is available from Blackall et al. (in preparation).

There is no evidence of a year-to-year lag of $\mathrm{NH} 3$ emissions from seabird-excreted $\mathrm{N}$ at the Isle of May. This is demonstrated by the return of $\mathrm{NH} 3$ concentrations to background levels over winter (Fig. 3). Surface pools of seabird-excreted $\mathrm{N}$ may diminish between breeding seasons as a result of complete volatilisation of available $\mathrm{N}$ during the post-fledging period or surface run-off during the winter. Cliff-nest sites are likely to be affected by surface run-off as there is little or no vegetation to intercept $\mathrm{N}$, resulting in loss to the sea and subsequent rapid dispersion by marine currents.

There was a reasonably high degree of local variability in $\mathrm{NH} 3$ concentrations measured at the Isle of May. Moving the sampling location at site G3 by approximately $3 \mathrm{~m}$ (from over the cliff edge to just above the cliff) resulted in a considerable decrease in measured $\mathrm{NH} 3$ concentration: from 158 ig rrT $^{3}$ in early June to 23 ig rrT $^{3}$ in the second half of June, a decrease that could not be apportioned to changes in bird numbers on the cliffs. This highlights the potentially high spatial variability in atmospheric $\mathrm{NH} 3$ concentrations near seabirds. To ascertain the magnitude of spatial variability in $\mathrm{NH} 3$ concentrations above guillemot cliffs, some targeted measurements were made in AprilMay 2002. Passive samplers were exposed for two 2-week periods at the top of cliffs with breeding guillemots on lower ledges. Triplicate samplers were attached to a pole at distances of $0.5,1.0$ and $1.5 \mathrm{~m}$ from the cliff edge at three separate locations on the west of the Isle of May. Fig. 7 shows that $\mathrm{NH} 3$ concentrations can vary significantly over short distances. This may be caused by complex dispersion patterns and turbulence at cliff-top locations.

The LADD model has been shown to produce comparable data to measured $\mathrm{NH} 3$ concentrations in relatively uncomplicated coastal terrain (Theobald et al., 2006). For the Isle of May, the LADD model did not produce accurate concentration predictions, being approximately an order of 

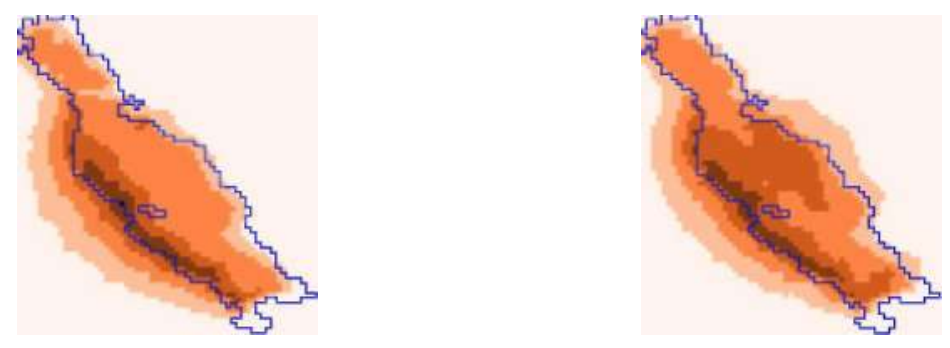

July 2000
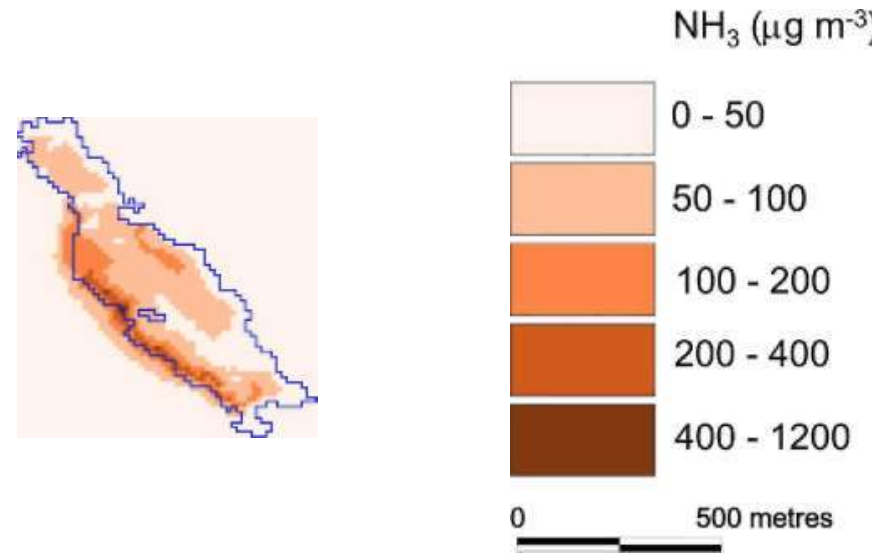

Fig. 5. Spatial GIS maps of predicted $\mathrm{NH}_{3}$ concentrations across the Isle of May for May-July 2000, based on a local area dispersion and deposition model (LADD).

magnitude higher than those observed by passive sampling (Fig. 6). This is most likely a result of complex dispersion parameters and turbulence above the seabird cliffs on the west of the Isle of May. Despite this, there was a strong correlation between measured and modelled concentrations for the cliff sites, but not inland sites (Fig. 6). The substantial absolute difference between the measured air concentrations and those modelled in LADD might be thought to cast doubt on the original estimates of ammonia volatilisation using a dispersion modelling approach (Blackall et al., 2004, 2007). This, however, is not an adequate explanation of the difference, and it is important to distinguish the use of models in relation to measurement of near-source and distant ammonia concentrations. The estimates of ammonia emission from the Isle of May derived by Blackall et al. (2007) were based on the comparison of a tracer ratio method and inverse application of a Gaussian model, from plume measurements typically $>1 \mathrm{~km}$ distance from the colony. The comparison of the two methods demonstrated the overall robustness of the approaches. By contrast, the present comparison considers near-source ammonia concentrations measured $\sim 0.5 \mathrm{~m}$ above the Isle of May surface with a multi-layer atmospheric dispersion model (LADD) using a gridded emission inventory. Models such as LADD are designed for application in rather flat area, and the LADD-measurement comparison most likely shows the limitations of applying the model to an area of extremely complex terrain.

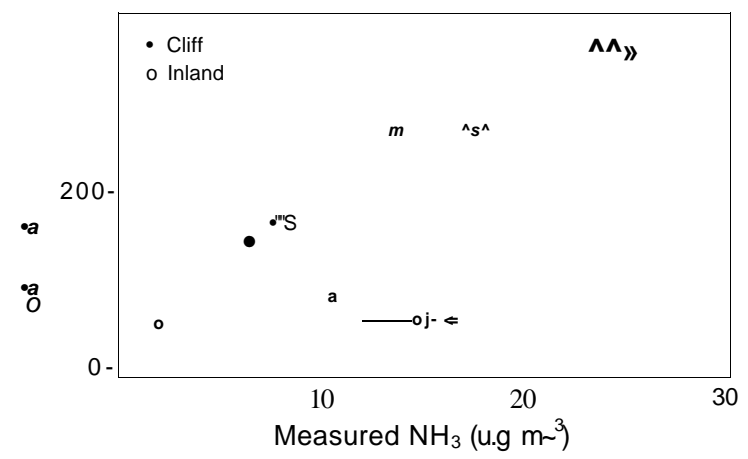

Fig. 6. Comparative plot of mean measured and modelled $\mathrm{NH}_{3}$ concentration for the period April 2000 to July 2001 for the passive monitoring sites on the Isle of May. Measured and modelled $\mathrm{NH}_{3}$ concentrations for 'Cliff sites showed a significant positive correlation (Pearson Correlation coefficient $=0.972$, sig. $=0.028, n=4$, whilst 'Inland' sites showed no significant correlation (Pearson Correlation coefficient $=-0.245$, sig. $=0.559, \mathrm{n}=8$ ). 

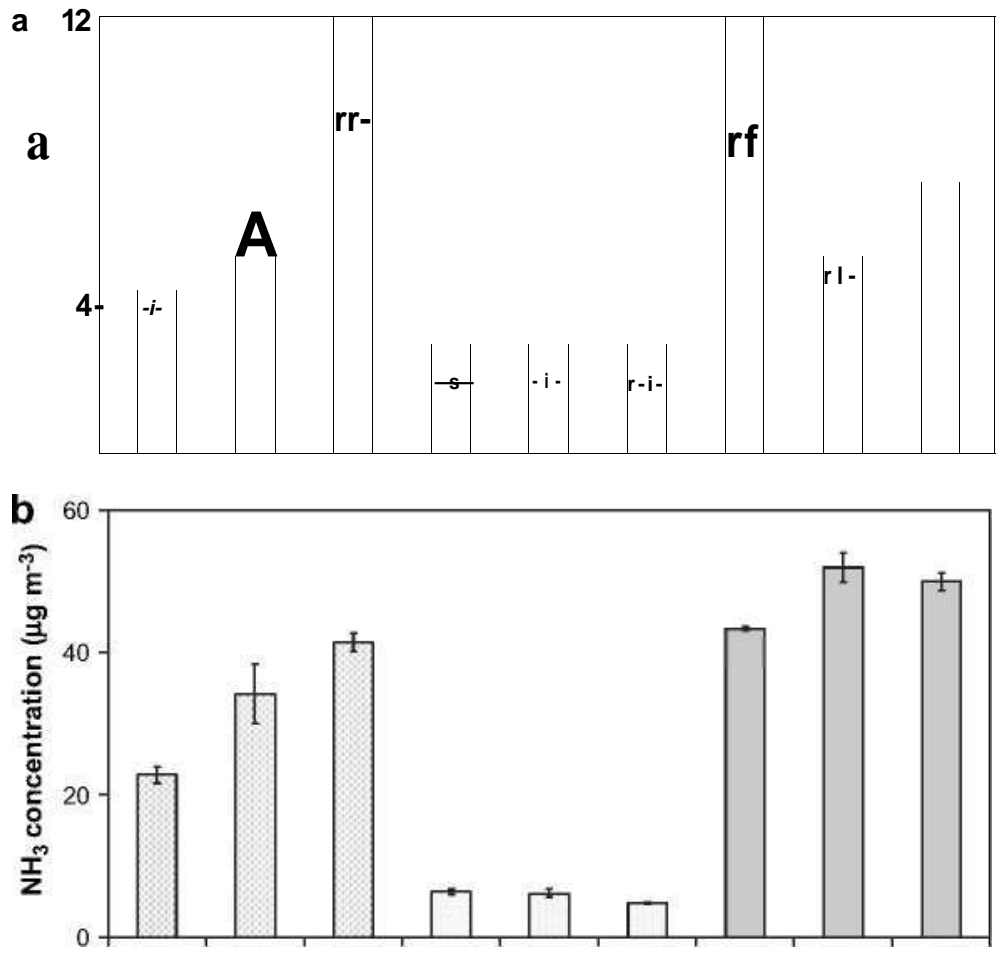

Fig. 7. $\mathrm{NH}_{3}$ concentrations at varying distances from the cliff edge for three locations above guillemot breeding ledges (G1, G2 G3) over two separate sampling periods (a) 17/04-01/05/2006 and (b) 01-15/05/2006. Error bars represent the standard error for three replicate ALPHA samplers at the distance stated.

The general spatial patterns of $\mathrm{NH} 3$ concentration observed at the Isle of May were as expected, with high concentrations above the most dense populations of barerock breeding birds (e.g. guillemot, razorbill, kittiwake, shag). An increase in seabird biomass should increase the concentration of $\mathrm{NH} 3$ observed in the vicinity of nesting birds. However, the $\mathrm{NH} 3$ concentrations at puffin colony sites (PI and P2) were generally low, despite their biomass being comparable to or higher than other species. It is likely that the more dispersed nesting behaviour of puffins (lower bird biomass per unit area), in addition to the presence of $\mathrm{NH} 3$-scavenging vegetation and greater dispersion potential over the fetch of the colony, resulted in the lower observed NH3 concentrations in the puffin colonies.

Despite the discrepancies between modelled and measured NH3 concentrations that have been outlined, the LADD model was generally able to produce $\mathrm{NH} 3$ concentration patterns that were representative of those observed at the colony (Fig. 5). The correlations between modelled and measured NH3 concentrations (Fig. 6) give an insight into the effect of nesting behaviour on $\mathrm{NH} 3$ volatilisation. The significant correlation for cliff nesting areas demonstrates that the volatilisation potential of $100 \%$, applied in our model, was reasonable. Furthermore, the position of the fitted line for inland locations, below that of cliff nesters, on Fig. 6 indicates that it is reasonable to assume that vegetation and burrow nesting species volatilise a lower proportion of the potential $\mathrm{NH} 3$ compared to cliff nesters. These findings strengthen the UK seabird emission estimates of Wilson et al. (2004) and global estimates of Blackall et al. (2007), as the majority of emissions in these estimates are from bare rock nesting birds. However, further research to determine the magnitude of emissions from vegetation and burrow nesting birds should be considered. It is likely that the $\mathrm{NH} 3$ volatilisation potentials applied to vegetation and burrow nesting species in this paper (70\% and 20\%, respectively) are too high.

\section{Conclusions}

A 14-month passive sampling campaign at the Isle of May seabird colony highlighted temporal and spatial patterns of $\mathrm{NH} 3$ concentration associated with different seabird species. Measured concentrations were highest near bare rock nesting Common guillemot and razorbill, with lower concentrations measured in areas with high numbers of burrow nesting Atlantic puffin. Measured NH3 concentration demonstrated a lag compared to modelled $\mathrm{NH} 3$ emissions, with an increase in correlation when comparing a modelled emission with the measured concentration for the following month. There was no 'carry-over' of NH3 emissions between different breeding seasons, as concentrations return to background during the winter months. Complex dispersion parameters are thought to have been the reason for near-source modelling of $\mathrm{NH} 3$ concentrations to exceed measured values, but spatial patterns of $\mathrm{NH} 3$ 
concentration generally corresponded with those observed across the Isle of May.

This paper highlights that volatilisation rates of $\mathrm{NH} 3$ from seabird-excreted $\mathrm{N}$ are likely to vary as a result of differing nesting behaviour, with higher emission from birds that nest on bare ground compared to vegetation/ burrow nesters. On the basis of comparisons in this study, it would appear that the percentage of ammonia volatilised from burrow nesting birds, compared to bare rock nesters, may be much lower than previously estimated. These findings strengthen seabird $\mathrm{NH} 3$ emission estimates (e.g. Wilson et al., 2004; Blackall et al., 2007), which are of importance to $\mathrm{NH} 3$ emissions inventories and the $\mathrm{N}$ budgets of remote coastal ecosystems. Future research is required to further clarify the effect of vegetation and burrow nesting on seabird $\mathrm{NH} 3$ emission potential.

\section{Acknowledgements}

We thank Scottish Natural Heritage for access to the Isle of May. Field assistance from Francis Daunt, Mike Harris, Mareike Moller-Holtkamp, Ian Parkinson and Jared Wilson is gratefully acknowledged. This work was supported by the UK Natural Environment Research Council (NERC) under the GANE (Global Nitrogen Enrichment) thematic program.

\section{References}

Bell, D., 1996. Isle of May national vegetation classification survey. Report for Scottish Natural Heritage.

Birt-Friesen, V.L., Montevecchi, W.A., Cairns, D.K., Macko, S.A., 1989. Activity-specific metabolic rates of free-living Northern Gannets and other seabirds. Ecology 70, 357-367.

Blackall, T.D, Hamer, K.C, Wanless, S., Sutton, MA A process-based model to describe ammonia emissions from seabird-excreted nitrogen In preparation

Blackall, T.D., Theobald, M.R., Milford, C, Hargreaves, K.J., Nemitz, E., Wilson, LJ., Bull, J., Bacon, P.J., Hamer, K.C., Wanless, S., Sutton, M.A., 2004. Application of tracer ratio and inverse dispersion methods with boat-based plume measurements to estimate ammonia emissions from seabird colonies. Water, Air, and Soil Pollution: Focus 4,279-285.

Blackall, T.D., Wilson, LJ., Theobald, M.R., Milford, C, Nemitz, E., Bull, J., Bacon, P.J., Hamer, K.C., Wanless, S., Sutton, M.A., 2007. Ammonia emissions from seabird colonies. Geophysical Research Letters 34 L10801. doi: 10.1029/2006GL028928.

Bouwman, A.F., Van Vuuren, D.P., Derwent, R.G., Posch, M., 2002. A global analysis of acidification and eutrophication of terrestrial ecosystems. Water, Air, and Soil Pollution 141, 349-382.

Bryant, D.M., Furness, R.W., 1995. Basal metabolic rates of North Atlantic seabirds. Ibis 137, 219-226.

Dragosits, U., Theobald, M.R., Place, C.J., Lord, E., Webb, J., Hill, J., ApSimon, H.M., Sutton, M.A., 2002. Ammonia emission, deposition and impact assessment at the field scale: a case study of sub-grid spatial variability. Environmental Pollution 117,147-158.

Elliot, HA, Collins, N.E, 1982. Factors affecting ammonia release in broiler houses Transactions of the American Society of Agricultural Engineers 25,413-424.

Elzing, A., Monteny, G.J., 1997. Ammonia emission in a scale model of a dairy-cow house. Transactions of the American Society of Agricultural Engineers 40, 713-720.

Fangmeier, A., Hadwinger-Fangmeier, A., Van der Eerden, L., Jager, H.J., 1994. Effects of atmospheric ammonia on vegetation - a review. Environmental Pollution 86, 43-82.

Fournier, N., Pais, V.A., Sutton, M.A., Weston, K.J., Dragosits, U, Tang, Y.S., Aherne, J., 2002. Parallelisation and application of a multi-layer atmospheric transport model to quantify dispersion and deposition of ammonia over the British Isles. Environmental Pollution 116, 95-107.
Hill, J.H., 1997. Applications of computational modelling to ammonia dispersion from agricultural sources. $\mathrm{PhD}$ thesis, University of London.

Hilton, G.M., Houston, D.C., Furness, R.W., 1998. Which components of diet quality affect retention time of digesta in seabirds? Functional Ecology 12, 929-939.

Koerkamp, P.W.G.G., Metz, J.H.M., Uenk, G.H., Phillips, V.R., Holden, M.R., Sneath, R.W., Short, J.L., White, R.P., Hartung, J., Seedorf, J., Schroder, M., Linkert, K.H., Pedersen, S., Takai, H., Johnsen, J.O., Wathes, CM., 1998. Concentrations and emissions of ammonia in livestock buildings in Northern Europe. Journal of Agricultural Engineering Research 70, 79-95.

LCM, 1990. The Land Cover Map of Great Britain. Centre for Ecology and Hydrology. Available from: http://www.ceh.ac.uk/sections/seo/lcm 1990.html (accessed 20.12.07).

Lee, D.S., Dollard, G.J., 1994. Uncertainties in current estimates of emissions of ammonia in the UK. Environmental Pollution 86, 267-277.

Misselbrook, T.H., Van Der Weerden, T.J., Pain, B.F., Jarvis, S.C., Chambers, B.J., Smith, KA, Phillips, V.R, Demmers, T.G.M., 2000. Ammonia emission factors for UK agriculture. Atmospheric Environment 34, 871-880.

Nemitz, E., Sutton, MA, Gut, A., San Jose, R., Husted, S., Schjoerring, J.K., 2000. Sources and sinks of ammonia within an oilseed rape canopy. Agricultural and Forest Meteorology 105, 385-404.

Nemitz, E., Milford, C, Sutton, M.A., 2001. A two-layer canopy compensation point model for describing bi-directional biosphereatmosphere exchange of ammonia. Quarterly Journal of the Royal Meteorological Society 127, 815-833.

Pearson, J., Stewart, G.R., 1993. The deposition of atmospheric ammonia and its effects on plants. New Phytologist 125, 283-305.

Singles, R., Sutton, M.A., Weston, K.J., 1998. A multi-layer model to describe the atmospheric transport and deposition of ammonia in Great Britain. Atmospheric Environment 32, 393-399.

Sobey, D.G., 1976. The effect of herring gulls on the vegetation of the Isle of May. Transactions of the Botanical Society of Edinburgh 42, 469-485.

Sutton, M.A., Asman, W.A.H., Schjoerring, J.K., 1994. Dry deposition of reduced nitrogen. Tellus 46B, 255-273.

Sutton, M.A., Fowler, D., Moncreiff, J.B., 1993a. The exchange of atmospheric ammonia with vegetated surfaces. 1. Unfertilized vegetation. Quarterly Journal of the Royal Meteorological Society $119,1023-1045$.

Sutton, M.A., Fowler, D., Moncreiff, J.B., Storeton-West, R.L., 1993b. The exchange of atmospheric ammonia with vegetated surfaces. 2. Fertilized vegetation. Quarterly Journal of the Royal Meteorological Society $119,1047-1070$.

Sutton, MA, Pitcairn, C.E.R., Fowler, D., 1993c. The exchange of ammonia between the atmosphere and plant communities. Advances in Ecological Research 24, 301-393.

Sutton, MA, Place, C.J., Eager, M., Fowler, D., Smith, R.I., 1995. Assessment of the magnitude of ammonia emissions in the UK. Atmospheric Environment 29,1393-1411.

Sutton, MA, Dragosits, U., Tang, Y.S., Fowler, D., 2000. Ammonia emissions from non-agricultural sources in the UK Atmospheric Environment 34, 855-869.

Tang, Y.S., Cape, J.N., Sutton, MA, 2001. Development and types of passive samplers for monitoring atmospheric $\mathrm{NO} 2$ and $\mathrm{NH} 3$ concentrations. The Scientific World Journal 1, 513-529.

Theobald, M.R., Crittenden, P.D., Hunt, A.P., Tang, Y.S., Dragosits, U., Sutton, M.A., 2006. Ammonia emissions from a Cape fur seal colony, Cape Cross, Namibia. Geophysical Research Letters 33, L03812.

Van Breemen, N., Burrough, PA., Velthorst, EJ., van Dobben, H.F., de Wit, T, Ridder, T.B., Reijnders, H.F.R., 1982. Soil acidification from atmospheric ammonium sulphate in forest canopy throughfall. Nature 299, 548-550.

Weathers, WW, 1992. Scaling nestling energy requirements. Ibis 134, 142-153.

Wilson, J.M. and Parkinson, R.I., 2000. Isle of May NNR general report 2000. Scottish Natural Heritage East Area Unpublished Report.

Wilson, LJ., Bacon, P.J., Bull, J., Dragosits, U., Blackall, T.D., Dunn, T.E., Hamer, KC, Sutton, M.A., Wanless, S., 2004. Modelling the spatial distribution of ammonia emissions from seabirds. Environmental Pollution 131,173-185. 